Bol. Zool. e Biol. Mar., N.S., n.o 30, pp. 217-232, São Paulo, 1973

\title{
FOOD AND FEEDING BEHAVIOR OF ARCTURELLA SAW AYAE MOREIRA, 1973 (CRUSTACEA, ISOPODA, VALVIFERA) *
}

\author{
PLINIO SOARES MOREIRA \\ Instituto Oceanográfico da Universidade de São Paulo \\ ALIMENTO E COMPORTAMENTO ALIMENTAR DE ARCTURELLA SAWAYAE, \\ MOREIRA, 1973 (CRUSTÁCEA, ISOPODA, VALVIFERA)
}

\section{RESUMO}

Jovens e fêmeas ovígeras de Arcturella sawayae Moreira, 1973, foram estudadas quanto ao hábito alimentar e comportamento relacionado à obtenção de alimento. As fêmeas $(7,9-8,3 \mathrm{~mm}$ de comprimento) foram capturadas na região de Ubatuba e em frente ao Instituto de Biologia Marinha, USP. Os jovens $(1,5 \mathrm{~mm}$ de comprimento médio) nasceram em laboratório. Fêmeas e jovens foram mantidos em aquários de água do mar corrente (Instituto de Biologia Marinha, São Sebastião) ou não (Instituto Oceanográfico, USP, São Paulo). Determinou-se que as fêmeas durante todo o período de reproduçāo e pós-reprodução não se alimentam. Experimentos de laboratório mostraram ser os jovens omnívoros, capazes de ingerir plantas e animais. Entretanto, apresentam marcante preferência por detritos (matéria orgânica particulada). São basicamente filtradores, coletando os detritos $\mathrm{em}$ suspensão com os primeiros pares de pereópodos, os quais funcionam como filtro. Também consomem detritos depositados na superfície de algas, quando o segundo par de antenas é o principal apêndice de coleta. Os jovens são extremamente sensíveis às correntes de água e sua direção. Consequentemente, seu comportamento difere segundo a velocidade e direção das correntes. A localização do alimento faz-se aparentemente sem a ajuda dos olhos e de receptores químicos, ambos os sentidos parecendo não estarem ainda bem desenvolvidos nos jovens. O mecanismo de obtenção de alimento (por filtração ou depositado) é discutido em relação à evolução dos apêndices orais nos Malacostraca, sendo o mesmo considerado como primitivo ou menos evoluido quando comparado as de outras espécies de isópodes. Como são fundamentalmente animais filtradores, os astacilídeos ocupam um nível trófico inferior a espécies de Idotea (omnivoras, necrófagas) e ainda mais inferior a espécies de Mesidotea e Eurydice (carnívoras, necrófagas).

\section{SUMMARY}

The kind of food ingested and the feeding behavior of reproductive females and juveniles of Arcturella sawayae Moreira, 1973, were studied. The animals were collected at Ubatuba and São Se-

* Publ. n. 344 Inst. Oceanogr. U.S.P 
bastiāo areas. In São Paulo they were kept in sea-water aquaria at the Instituto Oceanográfico, and in São Sebastião, Praia do Segredo, at the Instituto de Biologia Marinha, they were kept in continuous flowing sea water aquaria. Reproductive females do not eat. Laboratory experiments have shown that young animals are omnivoros feeders, eating a large variety of both plants and animals. However, they show a marked preference for detritus. The species is primarily a particulate filter feeder, collecting the organic matter in suspension with the first pereopods, which act as a sieving basket. They also perform deposit feeding, the antennae 2 being the main collecting appendages in this type of feeding. Juveniles are very sensitive to water currents and their direction. It was determined that the behavior of the animals varies according to the intensity and direction of the water flow. Water currents appear to be the primary cues for the onset of the feeding behavior. Filter feeding and deposit feeding seem to be executed without the use of the eyes and of chemical receptors, both senses apparently not yet fully developpea in younger stages. Feeding behavior and deposit feeding are discussed in relation to the evolution of the mouth appendages in the Malacostraca. Regarding these aspects they are considered as bearing a less evolved feeding mechanism than other species of isopods, at same time that they occupy a trophic level below Idotea and stils lower than Eurydice and Mesidotea.

\section{INTRODUCTION}

Studies on the various aspects of feeding by animals are valuable as they can provide informations regarding the food relationships between the species. The importance of the knowledge of the types of food consumed by a species, as well as, how the species are structurally armed to locate, gather and ingest it, have been stressed already (Young, 1928; Marshall and Orr, 1960). These kinds of informations are urged to be firstly known since they are basic for studies on trophic ecology (Greze, 1968; Leong and O'Connell, 1969).

The literature on the feeding behavior and feeding mechanism of isopod crustaceans is extremely sparse and fragmentary in nature. Essentially all the data currently available are confined to the types of food consumed by a species, usually revealed from the analyses of the gut content (Menzies, 1962; McCrimmon and Bray, 1962; Wolff, 1962; Dearborn, 1967; Narver, 1968). Few accounts report details or deal exclusively on the feeding mechanism (Kjennerud, 1952; Naylor, 1955; Green, 1957; Cruz, 1963).

Astacillid isopods are common component of the benthos, sometimes occurring in large number on seaweeds or on certain kinds of bottoms (author's unpublished data). This paper reports the results of laboratory experiments which were conducted in order to assess 
the types of food and the feeding behavior of both reproductive females and juveniles of Arcturella sawayae Moreira, 1973.

\section{MATERIAL AND METHODS}

Living Arcturella sawayae were observed in aquaria conditions. Reproductive females were collected in the Ubatuba area and placed in sea water aquaria at the Instituto Oceanográfico in São Paulo. Further specimens were collected off Praia do Segredo and kept in the Instituto de Biologia Marinha, São Sebastião, north littoral of State of São Paulo, in continuous flowing sea water aquaria. Nine reproductive females (size range 7.9-8.3 $\mathrm{mm}$ ) and 149 juveniles in the first and second post-marsupial stages (average length $1.5 \mathrm{~mm}$ ) were observed and used in the feeding experiments. For details on the aquaria conditions and on the animals watched see Moreira (1973 b).

A series of experiments were carried out to determine the type of food that both juveniles and adults may eat. For this the animals were fed experimentally. A variety of food was offered to them. The animals were not starved prior to the experiments. One hour was the time allowed to the animals to eat, afterwards an estimation of the food preference has been done from the diminished amount of food. Five experiments were conducted with each of the items listed below. The same experiments and the same kinds of food were given to both young and adults. However, reproductive females did not feed, overlooking all the types of food offered to them. Thus, the results obtained refer to juveniles, which in contrast to the females, present high feeding rate.

The food sources offered were: 1. particulate detritus (brown organic matter); 2. pieces of the brown seaweed Sargassum cymosum; 3 green algae (Ulva lactuca, Ulva fasciata and Desbesia sp.); 4 . morsels of fresh meat; 5 . fresh fish; 6.living copepods (Tisbe sp.); 7 living protozans; and 8 . animal remains.

\section{RESULTS}

Experiments $n^{\circ} 1$. These series of experiments were performed to determine the preferences and what type of food the juveniles can ingest. 
1. Green algae and organic detritus were given to the young. They ingested detritus, markedly, and also Derbesia sp., but not Ulva fasciata and Ulva lactuca.

2. The young were allowed to chose between Sargassum cymosum and detritus. It was found that they eat detritus, but not the alga, even when it was offered singly.

3. Fresh meat, fresh fish and animal remains were eaten indistinctly.

4. Living copepods (Tisbe sp.), as well as, living protozoans, were offered. The young did not try to eat these animals. In an experiment the number of Tisbe sp. and protozoans were so great, that they swan in large numbers just close to the body of the young. In spite of that, no juveniles tried to catch them, nor was there any evidence that copepods or protozoans were ingested.

5. All varieties of food were given simultaneously. Each of them apparently was eaten indistinctly, when encountered, except Sargassum cymosum, Ulva fasciata, Ulva lactuca, protozans and copepods. At the end of the experiment, however, a marked consumption of detritus over all the other food items was evident, animal remains, fresh fish, fresh meat and the grean alga Derbesia sp. following next.

All these experiments have shown that the juveniles of Arcturella sawayae are omnivorous feeders, capable of ingesting a variety of animal or vegetal food. They have also shown that in spite of their omnivorous habit, a primary selection of material is apparent, once various of the offered food varieties were not consumed.

In spite of the animals having been collected from Sargassum cymosum, this seaweed was not used as food. It is also highly improbable that larger immature specimens are able to eat it. No evidence was found that Sargassum and both species of Ulva were ingested. As both algae are much harder than Derbesia sp., it can be inferred that the animals are not structurally armed to consume them.

Thus, though detritus seems to constitute the bulk of food, green seaweeds and animal remains may be eaten when available, or when there is a shortage of detritus. Tiny fragment of animal remains may be utilized either deposited or in suspension in the water. Whether or not bacteria associated with them are an important food source it was not determined. 
The color of the fecal pellets depends on the type of the food consumed. The animals which eat green algae have greenish fecal pellets; when they eat particulate organic matter, the pellets are brownish; when fish meat is eaten, the pellets are whitish. The fecal pellets are cylindrical. The morphology is the same, whatever the type of food ingested.

A close examination of the fecal pellets, after the animals have ingested the detritus, has shown that they are formed by irrecognizable brown material consolidated into small cylindric bodies.

A selective action upon the material worked out by the mouth appendages seems to exist. The experiment described below was designed to answer this question.

Experiment n..$^{\circ}$ 2. Small entangled masses of detritus admixtured to minute quartzitic sand grains were given to the animals. It could be seen that these masses were worked out and sorted by the mouth appendages, the edible material (organic matter) being removed and ingested, while the sand grains were discarded. Under a close examination, the fecal pellets have shown a complete absence of sand grains, though the pellets have been carefully searched for them. This experiment was repeated 5 times with 5 animals each time, and the results were similar. Thus, it seems clear that the food worked out by the oral appendages is selected in order to be ingested.

When the animals were fed with filaments of the green alga Derbesia sp., it could be observed that each filament was not cut into small pieces, but only smashed and so ingested in all its length. Examination of the fecal pellets showed each pellet as composed of a sigle, compressed greenish filament, that could easily be spread out. It is clear that the green filamentous alga passed through the digestive-tract without being ground beyond recognition. The greenish color was due to the presence of chloroplasts. Because the fecal pellets could be spread out into a filament, this indicates that the celular walls were not completely destroyed.

The partial smashing of the seaweed is the result of the absence of suitable structures to break the algae walls efficiently. It also seems likely that cellulase is not produced, at least at these younger developmental stages, since the seaweed passed through the digestive-tract apparently without large change. The presence of chloroplasts indi- 
cates that a more efficient grinding work is required before the enzymes are able to act on the cytoplasm.

Although the young animals are able to eat green algae, at this stage they are not well equipped to consume them efficiently. Undoubtedly, this stresses the character that these animals are primarily particulate detritus consumers.

\section{Suspension feeding behavior}

It has been shown that young animals can feed on a variety of food. However, a clear preference to particulate detritus was encountered. This type of food can be found in nature floating in the water as suspended organic matter, or settling on seaweeds, animals etc.

Young Arcturella sawayae are structurally well armed to collect detritus either in suspension or deposited. Depending of the water currents and the availability of food, they can act as a suspension or as a deposit feeder. As they are basically structured to obtain organic matter in suspension in the water, most of the food consumed is naturally gathered in this way.

When collecting food as particulate suspended organic matter the animals assume a very distinctive posture (filter feeding posture): body well elevated, all first pereopods outstetched, antennae 2 direct forward, bent slightly down and lightly opened. The animals must not necessarily be in normal position to gather food in suspension. Those clinging to the female's antennae with head downward do it efficiently also.

The first pereopods are by far the most important functional appendages in this process of feeding. For details of the pereopods I-IV and their setal armature see Moreira (1973 a). When completely outstretched the first pereopods act as a sieving basket. The animals must face the direction of the water current to collect suspended material. All matter carried out by the water is thus retained by the filter screen formed by the pereopod setae.

The organic mattei accumulated in the sieving basket is from time to time collected through rapid movements of the first pair of pereopods, then gathered by the maxilliped palps and finally passed forward to the other mouth appendages. Similarly, detritus accumu- 
lated on the antennae 2 are collected also, with the antennae being closed towards the mouth and brushed by the first pair of pereopods.

All these food gathering movements are rapidly performed. They are repeated several times successively, until both antennae and pereopods are cleaned from deposited material. The number of times that the animals perform these collecting movements depends on the deposition rate of the material on the antennae and pereopods, which in turn is a function of the amount of particulate matter suspended in the water.

Considering the sites where the gravid females have been collected, which are under the influence of moderate water movement, rich in suspended organic matter, and in order to investigate possible exogenous cues for the onset of the feeding behavior, two distinct series of experiments have been conducted. In both series of experiments detritus were stirred up in a bottle and thus reduced to smaller particles. Different sizes of pippetes have been used to produce water currents carrying abundant organic material in suspension. The experiments have been performed upon one animal each time, and each series of experiments has been repeated 10 times.

Experiment $n .^{\circ} 3$. This experiment was especially designed to investigate the reaction of the animals to a weak water current and its direction.

A weak or moderate water current reaching the animal from backwards, causes a prompt reaction which consists in the rotating of the body $180^{\circ}$ to face the current, and the immediate assumption of the suspension feeding posture. Similar reactions are displayed by animals performing deposit feeding in still water. As soon as the artificially produced water current reaches them from backwards, they promptly stop feeding, turn $180^{\circ}$ to face the current, and assume the suspension feeding posture. The reaction they display when the water current faces the animals while they perform their deposit feeding is the normally expected, i.e., they lift the fore portion of the body, assuming the suspension feeding posture.

Experiment n. 4. This experiment was undertaken in order to assess the reaction of the young animals to a strong water current and to its direction. 
An animal being reached from backwards by a strong water current reacts promptly assuming an unexpected but highly functional posture. He extends the body forward, parallel and close to the seaweed, the first pereopods tightly juxtaposed to the mouth covering the oral appendages, the second antennae extending straight forward, also close to the seaweed.

However, when a strong water current faces the animal, he reacts promptly and very quickly rotating the body $180^{\circ}$ so as to receive the impact of the flow posteriorly. The posture he then assumes is the one just described, i.e., body parallel to the direction of the flow and extended forwards close to the seaweed surface.

Experiment $n .^{\circ} 5$. This experiment was undertaken to assess the importance of the water current in initiating the suspension feeding activity, as well as to verify if the turbidity of the water could have influence in initiating the suspension feeding.

Young animals were placed in a dish with still water having minute particles of detritus in suspension. In such a condition it was observed that the animals perform deposit feeding movements only. However, as soon as they are reached by an artificially produced water current, they promptly react assuming the suspension feeding posture.

In clear still water, devoid of organic particles in suspension, the animals display the deposit feeding movements. However, as soon as a water current is produced, the suspension feeding posture is assumed; if the flow of water is maintained, the animals continue to display that posture waiting the deposition of material (in this case absent) on the first pereopods.

\section{Deposit feeding behavior}

Juveniles perform deposit feeding either in the absence of a water current, either as an alternate method of gathering food, when the surrounding waters are impoverished of particulate suspended matter.

To perform deposit feeding the animal bends forward the anterior portion of the body, and with the second antennae almost straight and slightly outstretched, scrapes with their tip the surface of the 
alga. As soon as a masse of detritus is found, the distal portion of the antennae is bent tightly inward against the other antennal segments, firmly securing the collected mass of detritus; immediately afterwards the antennae are drawn towards the mouth so that they can be reached by the first pair of pereopods, which brushes them, collecting the food.

Moving the fore part of the body from one side to the other, the animal explores with the antennae 2 all the area at their anterior and lateral sides. Following each or after several scraping movements, after having or not collected a massa of detritus, the antennae are drawn towards the mouth so that they can be brushed by the pereopods I.

After all the particulate organic matter from either side of the animal has been collected, it walks forwards a little, reasuming the deposit feeding movements again, independetly of the presence of the food. Nothing being found, it walks again reasuming the feeding movements a little further on, and so forth. The animal usually remains exploring an area until this has become depleted of detritus, and only afterwards moving on to a fresh area.

The characteristic posture assumed by the animals while the mouth appendages are working out the food is the body erect, the first pereopods slightly outstretched, the antennae 2 lightly opened, decurved and extended forwards immobile. When the collected organic masse is large, both the antennae 2 and the first pereopods help the pereopods I to hold it, while the maxillipeds, palps and remaining mouth appendages are working out part of the material.

\section{DISCUSSION}

The present observations on the food and feeding behavior of Arcturella sawayae have shown interesting aspects to be evaluated and discussed.

Many isopods once reaching maturity stop feeding (Hansen, 1905; Naylor and Quénisset, 1964; White, 1970; Bastida and Torti, 19691970; Moreira, 1971). Reproductive females of Arcturella sawayae follow this pattern, which seems to be widespread among marine isopods. On the contrary, young animals show a high feeding rate, as 
expected by Naylor and Quénisset (1964) to occur also in juveniles of Naesa bidentata. At the younger developmental stages Arcturella sawayae lives to obtain food and to eat. Gathering of food is their major problem. Most of the motions performed at this time are directly or indirectly associated with the obtention of food.

Marine animals may be characterized according to their feeding type (Blegvad, 1914; Hunt, 1925; Young, 1928; Marshall and Orr, 1960). Many isopods are omnivorous feeders (Wolff, 1962; Cruz, 1963; Dearborn, 1967; Jones et al., 1969; Narver, 1968; Bastida and Torti, 1969-1970; Tsikhon-Lukanina, 1970). It has been shown that younger Arcturella sawayae are also omnivorous feeders, able to eat a large variety of food. Laboratory experiments have shown that they can gather many food types when available, but that they have a marked preference for particulate organic matter (detritus) over all other items. It has also being found that the collected material is previously selected by the mouth appendages before ingestion (Experiments $n .^{\circ}$ 1 and 2).

Detritus is found in suspension or deposited, the animals being able to collect it either in suspension (filter feeding) or deposited (deposit feeding). Arcturella sawayae are well equipped to perform both types of feeding efficiently. Their behavior, as well as the main appendages employed and how they work in both feeding process, have been described. Neither young Arcturella sawayae nor Astacilla longicornis (Hult, 1941) were observed displaying the feeding method reported by Goodsir (1841, apud Harger, 1880) in some species of Astacilla, i.e., "it frequently darts from its branch, with the rapidity of lightning, to seize with its long antennae some minute crustacean animal, and returns to its resting place to devour its prey at pleasure" It seems from all these that a wide range of feeding habits may exist amongst the species of astacillids.

There is a well defined relation between the habitat, and the availability of food and the type of feeding mechanism. Similarly, a number of contributions have pointed out in species of marine isopods the relationship between the structure and functions of the feeding appendages and the feeding habit (Tait, 1926; Nicholls, 1931; Naylor, 1955; Green, 1957).

The main appendages employed by astacillids in the filter feeding are the first pereopods, which with their equipment of setae form an 
efficient sieve apparatus. To perform the deposit feeding the main appendages are the antennae 2. It was shown that this is an active voluntary process of feeding, through which the animal can seize food from the surface of plants or from the surface of the substrate.

The first pereopods have no active participation in the deposit feeding process, nor in the trials performed by the young to find a suitable projection for to grip on (Moreira, $1973 \mathrm{~b}$ ). Such observations seem highly interesting, since they stress the highly specialized function of the first pereopods (food filter), in a remarkable relationship between morphology and function. At the same time, experiments have already shown the perfect adaptation of these animals for to live gripped on to projecting structures (Moreira, $1973 \mathrm{~b}$ ).

Many crustaceans have also developed an adaptative filter feeding process (Pearse, 1913; Cannon, 1927; Nicol, 1932; Lowndes, 1933; Marshall and Orr, 1955). However, the food filter may be represented either by any of the mouth appendages or by other appendages of the head and pereon, and not solely by the first pereopods, as in the astacillids. Filter feeding is performed, for instance, by the first or second antennae by the amphipod Haploops tubicola (Eniquist, 1949) and by the decapods Emerita talpoida and Emerita analoga (MacGinitie and MacGinitie, 1968), while the decapod Hapalocarcinus marsupialis (Potts, 1915) uses the first and second maxillipeds.

Cannon and Manton (1927, 1929), Cannon (1928), Manton (1928) and Dennel $(1933,1937)$ have discussed the functional evolution of the mouth parts in Crustacea. Cannon and Manton (1929) pointed out that the primitive feeding-habit of the Malacostraca was filtratory. In the higher forms of Syncarida, Peracarida and Eucarida this method of feeding has been lost, and substituted by a raptorial feeding method.

In the light of the studies on the functional evolution of the mouth parts in the Malacostraca (Cannon and Manton, 1929; Dennel, 1937), and based on the studies of the feeding habit and feeding mechanism in Idotea by Naylor (1955), in Mesidotea entomon by Narver (1968), and in Eurydice by Jones (1968) and Jones et al. (1969), the astacillids are comparatively less evolved regarding their feeding mechanism. At the same time, being primarily detritus filter feeding animals, they occupy a lower trophic level than Idotea (omnivorous scavengers) and still lower than Eurydice and Mesidotea (both carnivorous, scavengers animals). 
Experiments n. 3 and 4 have shown the probable exogenous cues involved in the onset of both filter feeding and deposit feeding process. It was observed that young animals are very sensitive to water movements, reacting quickly to both a stream of water and its direction. The reactions of the animals depend on the intensity of the flow of the stream. In a moderate or weak current the animals always face it, assuming the typical filter feeding posture. However, when a strong water current faces them, but it being not so strong as to provoque their dislodgement, the animals assume a safe posture, rotating the body quickly $180^{\circ}$ in order to receive the impact of the current from posteriorly. In this case, feeding is not performed in behalf of self-preservation.

It appears that this position displayed by young animals is highly functional and the safest one. Their receiving the direct impact of the water current from posteriorly avoids problems of dislodgement as the posterior pereopods are stout and hold the animals firmly to the substrate. The rapid change of position executed by the young animals is highly interesting. It is a very characteristic and functional movement of self-preservation performed by them.

It seems that water currents are indications of the presence of suspended organic food, and are likely to be the primary cues for the filter feeding activity. The results of the Experiment $n .^{\circ} 5$ seem to demonstrate this.

It was seen that deposit feeding is performed by young animals either in the absence of a water current, or as an alternate method of obtention of food. It is especially important when the surrounding waters are impoverished of particulate suspended material. Two points should be stressed in relation to this process of feeding. First, the most important appendages employed in this food gathering process are the second antennae. Second, it seems that this process of collecting food is blind or fortuituous. It appears that the animals at this stage of development are not able to fully use vision, once they perform the food gathering movements independently of the presence of detritus in a place. Chemical receptors seem to be not yet fully developed. Available reports have shown in many marine crustaceans the presence of highly developed chemical receptors (Prosser and Brown, 1961; Lockwood, 1968). However, most of these receptors were not yet identified precisely in marine isopods. 


\section{CONCLUSIONS}

1. Reproductive females do not feed. On the contrary, juveniles spend most of their time gathering food to eat.

2. Young animals are omnivorous, eating a large variety of food (animals and plants). However, they show a clear preference for particulate organic matter (detritus). Green tender seaweeds and animals remains may be eaten when available or when there is a shortage of detritus. It appears that the animals are not structurally well armed to consume algae efficiently. It also seems that cellulase is not produced in these developmental stages.

3. The animals are primarily particulate detritus feeders. This matter can be collected either in suspension or when deposited. The juveniles are well armed to display filter feeding and deposit feeding.

4. The first pairs of pereopods are the most important functional appendages in the filter feeding, acting as an efficient sieving basket owing to their setal armature. The material accumulated on them are collected by the first pair of pereopods, then gathered by the maxillipedal palps and passed forward to the other mouth appendages. Owing to the small slze of the young animals, it was difficult to study in detail the work performed by each of the oral appendages.

5. Juveniles react to water currents and their direction. The reaction varies according to the intensity of the current. In a moderate or weak flow, they display the filter feeding behavior. In strong water streams, the juveniles react always assuming a safety posture.

6. Water currents seem to be the primary cues for the onset of the filter feeding process.

7 Deposit feeding is performed either in the absence of a water current, or as an alternate method of gathering food, when the waters are depleted of particulate suspended matter.

8. The second antennae are the main appendages in the deposit feeding. This type of feeding is voluntary. It seems to be blind, once it is performed independently of the presence of deposited detritus on the surface of the algae.

9 The eyes are not used by young animals to locate deposited detritus. Chemical receptors are not used too, appearing that both sense receptors are not fully developed at the younger stages. 
10. Regarding their feeding mechanism (the filtratory habit of the astacillids are discussed in view of previous studies on the functional evolution of the mouth parts in the Malacostraca), the astacillids seem to be less evolved comparatively to other species of isopods.

11. Being primarily filter feeders, astacillids occupy a trophic level lower than Idoted (omnivorous, scavengers animals), and still lower than Eurydice and Mesidotea (carnivorous, scanvengers animals).

\section{A C K N O W L E D G E M E N T S}

To Professor Dr. Paulo Sawaya, Director, Instituto de Biologia Marinha, USP, I am deeply indebted for place at my disposal all the facilities of the Instituto de Biologia Marinha in São Sebastião. Special thanks also to Prof. Dr. Tagea K. S. Björnberg, from the Department of Zoology, USP, for the correction of the English text.

I am very pleased to make this contribution in honor of Professor Dr. Paulo Sawaya.

\section{R E F E R E N E S}

BASTIDA, R. \& TORTI, M. R. (1969-1970) - Crustaceos Isopodos: Serolidae. Résult. scient. Camp. Calypso, n. ${ }^{\circ}$ IX. Annls Inst. oceanogr. Monaco, n.s., vol. 47 (fasc. unique) :61-105.

BLEGVARD, H. (1914) - Food and conditions of nourishment among communities of invertebrate animals found on or in the sea bottom in Danish waters. Rep. Danish Biol. Stat., n. ${ }^{\circ} 22: 41-78$.

CANNON, H. G. (1927) - On the feeding mechanism of Nebalia bipes. Trans. Roy. Soc. Edinburgh, 55:355-369.

CANNON, H. G. (1928) - On the feeding mechanism of the fairy shrimp, Chirocephalus diaphanus Prévost. Trans. Roy. Soc. Edinburgh, 55:807-822.

CANNON, H. G. \& MANTON, S. M. (1927) - On the feeding mechanism of a mysid crustacean, Hemimysis lamornae. Trans. Roy. Soc. Edinburgh, 55: 219-253.

CANNON, H. G. \& MANTON, S. M. (1929) - On the feeding mechanism of the syncarid Crustacea. Trans. Roy. Soc. Edinburgh, 56:175-189.

CRUZ, A. A. de la (1963) - Observations on the feeding activity of the isopod Idothea baltica (Pallas). Seto Mar. Biol. Lab., 11(1):165-170, pl. 10.

DEARBORN, J. H. (1967) - Food and reproduction of Glyptonotus antarcticus (Crustacea: Isopoda) at McMurdo Sound, Antarctica. Trans. Roy. Soc. New Zeal., zool., 8(15):163-168.

DENNEL, R. (1933) - The habits and feeding mechanism of the amphipod Haustorius arenarius Slabber. J. Linn. Soc. Lond., zool., 38:363-388. 
DENNEL, R. (1937) - On the feeding mechanism of Apseudes talpa and the evolution of the peracaridan feeding mechanisms. Trans. Roy. Soc. Edinburgh, 59:57-78.

ENIQUIST, P. (1949) - Studies on the soft-bottom amphipods of the Skagerak. Zool. Bidrag Uppsala, 28:295-492.

GOODSIR, H. D. S. (1841) - On two new species of Leachia, with a plate. Edinburgh New Philos. Journ., 31:309-313, pl. 6.

GREEN, J. (1957) - The feeding mechanism of Mesidotea entomon (Linn.) (Crustacea: Isopoda). Proc. zool. Soc. Lond., 129(2):245-254.

GREZE, I. I. (1968) - Feeding habits and food requiriments of some amphipods in the Black Sea. Marine Biol., 1(4):316-321.

HANSEN, H. J. (1905) - On the propagation, structure and classification of the family Sphaeromidae. Quart. J. micros. Sci., 49:69-135.

HARGER, O. (1880) - Report on the marine Isopoda of New England and adjacent waters. Report U. S. Commissioner Fish and Fish., part VI, 1878, p. 297-462, pls. 1-13.

HULT, J. (1941) - On the soft-bottom isopods of the Skager Rak. Zool. Bidr. Uppsala, 21:1-234.

HUNT, O. D. (1925) - The food of the bottom fauna of the Plymouth Fishing grounds. J. mar. biol. Ass. U. K., 13:560-599.

JONES, D. A. (1968) - The functional morphology of the digestive system in the carnivorous intertidal isopod Eurydice. J. Zool., Lond., 156:363-376.

JONES, D. A.; BABBAGE, P. C. \& KING, P. E. (1969) - Studies on digestion and fine structure of digestive caeca in Eurydice pulchra (Crustacea: Isopoda). Mar. Biol., 2(4):311-320.

KJENNERUD, J. (1952) - Ecological observations on Idotea neglecta G. O. Sars. Univ. Bergen Arb. (Naturv. rekke), 7:1-47.

LEONG, R. J. H. \& O'CONNELL, C. P. (1969) - A laboratory study of particulate and filter feeding of the northern anchovy (Engraulis mordax). J. Fish. Res. Bd. Canada, 26(3):557-582.

LOCKWOOD, A. P. M. (1968) - Aspects of the physiology of Crustacea. Oliver and Boyd, Edinburgh, 328 p.

LOWNDES, A. G. (1933) - The feeding mechanism of Chirocephalus diaphanus Prévost, the fairy shrimp. Proc. Zool. Soc., Lond., n. ${ }^{\circ}$ 1933:1093-1118.

MACGINITIE, G. E. \& MACGINITIE, N. (1968) - Natural history of animals. New York, McGraw-Hill Book Co., 523 p.

MANTON, S. M. (1928) - On some points in the anatomy and habits of the lophogastrid Crustacea. Trans. Roy. Soc. Edinburgh, 56:103-119.

MARSHALL, S. M. \& ORR, A. P. (1955) - The biology of a marine copepod Calanus finmarchicus (Gunnerus). Oliver e Boyd, Edinburgh, 188 p. 
MARSHALL, S. M. \& ORR, A. P. (1960) - Feeding and nutrition. In: WATERMAN, T. H., ed. - The physiology of Crustacea, vol. I. New York and London, Academic Press, p. 227-258.

MENZIES, R. J. (1962) - On the food and feeding habits of abyssal organisms as exemplified by the Isopoda. Int. Reveu ges. Hydrobiol., 47(3):339-358.

McCRIMMON, H. \& BRAY, J. (1962) - Observations on the isopod Mesidotea entomon in the Western Canadian Arctic ocean. J. Fish. Res. Bd. Canada, $19(3): 489-496$.

MOREIRA, P. S. (1971) - Fisioecologia de isópodes do gênero Serolis Leach, 1818 (Crustacea, Serolidae). 297 pp. + atlas. Livre Docência Thesis. University of São Paulo.

MOREIRA, P. S. (1973 a) - Arcturella sawayae a new species of Isopoda Crustacea from southern Brazil. Bol. Zool. e Biol. Mar., n.s. (in press).

MOREIRA, P. S. (1973 b) - Behavioral aspects of Arcturella sawayae Moreira, 1973 (Crustacea, Isopoda, Valvifera). Bol. Zool. e Biol. Mar., n.s. (in press).

NARVER, D. W. (1968) - The isopod Mesidotea entomon in the Chignik Lakes, Alaska. J. Fish. Res. Bd. Canada, 25(1):157-167.

NAYLOR, E. (1965) - The life cycle of the isopod Idotea Emarginata (Fabricius). J. Anim. Ecol., 24(2):270-281.

NAYLOR, E. \& QUENISSET, D. (1964) - The habitat and life history of Naesa bidentata (Adams). Crustaceana, 7(3):212-216.

NICHOLLS, A. G. (1931) - Studies on Ligia oceanica. II. The process of feeding, digestion and absorption with a description of the structure of the foregut. J. mar. biol. Ass. U. K., 17:675-708.

NICOL, E. A. T. (1932) - The feeding habit of the Galatheidae. J. mar. biol. Ass. U. K., 18:87-106.

PEARSE, A. S. (1913) - On the habits of the crustaceans found in Chaetopterus tubes at Wood's Hole, Massachussetts. Biol. Bull., 24:102-114.

POTTS, F. A. (1915) - Hapalocarcinus, the gall-forming crab, with notes on the related genus Cryptochirus. Carnegie Inst. Wash. Publ., 212:33-69.

PROSSER, C. L. \& BROWN, F. R. (1961) - Comparative animal physiology. 2nd ed. Saunders, Philadelphia, $614 \mathrm{pp}$.

TAIT, J. (1926) - Experiments and observations on Crustacea. Part VII. Some structural and physiological features of the valviferous isopod Chiridotea. Proc. Roy. Soc. Edinburgh, 46:334-348.

WHITE, M. G. (1970) - Aspects of the breeding biology of Glyptonotus antarcticus (Eights) (Crustacea, Isopoda) at Signy Island, South Orkney Islands. In: HOLDGATE, M. W., ed. - Antarctic ecology. London, Academic Press, vol. I, p. 279-285.

WOLFF, T. (1962) - The systematics and biology of bathyal and abyssal Isopoda Asellota. Galathea Rep., 6:1-320, pls. 1-19.

YOUNG, C. M. (1928) - Feeding mechanisms in the invertebrates. Biol. Reviews, Cambridge Philos. Soc., 3(1):21-76. 